\title{
TERAPI INSULIN SEBAGAI ALTERNATIF PENGOBATAN BAGI PENDERITA DIABETES
}

\author{
Oleh: Cerika Rismayanthi \\ Dosen Jurusan Pendidikan Kesehatan dan Rekreasi FIK UNY
}

\begin{abstract}
ABSTRAK
Diabetes Mellitus (DM) merupakan salah satu masalah kesehatan yang berdampak pada produktivitas dan dapat menurunkan sumber daya manusia. Penyakit ini tidak hanya berpengaruh secara individu, tetapi sistem kesehatan suatu negara. Walaupun belum ada survey nasional, sejalan dengan perubahan gaya hidup termasuk pola makan masyarakat, diperkirakan penderita DM semakin meningkat, terutama pada kelompok umur dewasa ke atas pada seluruh status sosial ekonomi. Saat ini upaya penanggulangan penyakit DM belum menempati skala prioritas utama dalam pelayanan kesehatan, walaupun diketahui dampak negatif yang ditimbulkannya cukup besar antara lain komplikasi kronik pada penyakit jantung kronis, hipertensi, otak, system syaraf, hati, mata dan ginjal. DM merupakan salah satu penyakit degeneratif, dimana terjadi gangguan metabolisme karbohidrat, lemak dan protein serta ditandai dengan tingginya kadar gula dalam darah (hiperglikemi) dan dalam urin (glukosuria).

Kini ditemukan jenis insulin yang bisa disuntikkan satu kali sehari. Penyakit diabetes mellitus atau kencing manis memang tak bisa dianggap remeh. Bagi pasien DM I atau beberapa pasien diabetes mellitus tipe II (DM II) terapi insulin wajib hukumnya. Injeksi insulin menjadi keharusan karena hormone insulin pada tubuh penderita diabetes mellitus tidak bisa dihasilkan, atau tidak dapat digunakan dengan baik. Dalam tubuh hormone insulin diperlukan untuk mengangkut glukosa dari darah masuk ke sel. Karena tak mampu melakukan pengangkutan gula ke sel, maka pasien DM mempunyai kadar glukosa tinggi dalam darahnya. Keadaan ini dikenal sebagai gula darah tinggi atau hiperglikemi. Hormone insulin ini dikeluarkan oleh organ tubuh yang bernama pankreas.
\end{abstract}

Kata Kunci : insulin, diabetes mellitus. 
Menurut Unggul Pribadi (2006), DM atau kencing manis adalah suatu penyakit yang disebabkan oleh karena peningkatan kadar gula dalam darah (hiperglikemi) akibat kekurangan hormone insulin baik absolute maupun relatif. Absolut berarti tidak ada insulin sama sekali, sedangkan relatif berarti jumlahnya lebih rendah dari kebutuhan atau daya kerjanya kurang. Hormone insulin dibuat dalam Pancreas. Ada 2 tipe DM :

1. DM tipe I. atau disebut DM yang tergantung pada insulin. DM ini disebabkan akibat kekurangan insulin dalam darah yang terjadi karena kerusakan dari sel beta pancreas. Gejala yang menonjol adalah terjadinya sering kencing (terutama malam hari), sering lapar dan sering haus, sebagian besar penderita DM tipe ini berat badannya normal atau kurus. Biasanya terjadi pada usia muda dan memerlukan insulin seumur hidup.

2. DM tipe II atau disebut DM yang tidak tergantung pada insulin. DM ini disebabkan insulin yang ada tidak dapat bekerja dengan baik, kadar insulin dapat normal, rendah atau bahkan meningkat tetapi fungsi insulin untuk metabolisme glokosa tidak ada/ kurang. Akibatnya glukosa dalam darah tetap tinggi, sehingga terjadi hiperglikemi, $75 \%$ dari penderita DM tipe II dengan obersitas atau sangat kegemukan dan biasanya diketahui DM setelah usia 30 tahun.

Menurut Soegianto Wibisono (2009), “Hormon yang mengatur kadar glukosa darah tubuh untuk tetap berada pada batas normal, "Gejala-gejala diabetes, di antaranya trias poli (3P), yaitu poliuri (banyak kencing), polidipsi (banyak minum), dan politagi (banyak makan). Biasanya berat badan juga menurun drastis, kesemutan, terjadi gangguan mata, dan disfungsi ereksi, yang merupakan gejala-gejala klasik yang umumnya terjadi pada penderita. Namun, mungkin saja tak ada gejala yang dirasakan penderita. Jika begini biasanya baru beberapa tahun kemudian ketahuan penyakitnya. Oleh karena itu, seseorang yang memiliki riwayat keluarga penderita DM sebaiknya memeriksakan gula darah setidaknya satu kali setahun. Tentu harus diiringi dengan diet, olahraga dan pola hidup yang sehat. Apalagi, saat ini telah terjadi pergeseran usia penderita. Jika sebelumnya pasien DM cenderung usia cukup tua, maka kini orang usia muda sudah banyak yang terkena DM. Memang ada kecenderungan peningkatan pasien usia muda. Banyak dari pasien saya pada usia 20 tahun hingga 30 tahun sudah terkena DM. Ini karena pola hidup tak sehat kian banyak terjadi di masyarakat. Pola makan yang salah dan kurang gerak badan, misalnya, bisa menjadi faktor pencetus DM. Faktor pencetus DM lainnya adalah infeksi virus, kegemukan, minum obat yang bisa menaikkan kadar gula darah, penuaan, dan stres.

\section{Pengobatan Diabetes}

Tujuan pengobatan diabetes pada dasarnya adalah mengontrol glikemi atau gula darah hingga mencapai kadar gula yang mendekati normal (kadar gula darah orang sehat). Namun, di tengah pengobatan ini harus dicegah terjadinya hipoglikemi atau kadar gula darah yang terlalu rendah. Bila tujuan tersebut tidak dicapai, maka penderita diabetes 
akan merasa lebih sehat dan menikmati kualitas hidup yang lebih baik. Selain itu, timbulnya komplikasi yang serius dan mengancam jiwa penderita dapat dicegah.

Menurut Ruslianti (2008) pengobatan diabetes harus dikelola melalui beberapa tahapan yang paling terkait. Pengelolaan diabetes ini meliputi edukasi, perencanaan makan, latihan jasmani, dan penggunaan obat-obatan, baik oral maupun insulin. Terapi insulin wajib diberikan pada penderita DM I pada penderita DM II, sekitar 40 persenya juga harus menjalani terapi insulin. Tes gula darah dapat secara efektif menentukan jumlah insulin yang dibutuhkan setiap harinya.

Menurut Ruslianti (2008) terapi insulin yang dianjurkan adalah saat pagi hari sebelum sarapan, dua jam setelah makan, dan malam hari sebelum tidur. Selain itu, diperlukan pula pengukuran pada saat tertentu, misalnya pengukuran yang lebih ketat jika terjadi hipoglikemi, saat sebelum olahraga, dan pada kehamilan. Pengobatan diabetes bisa dikatakan berhasil jika glukosa darah puasa adalah 80 sampai $109 \mathrm{mg} / \mathrm{dl}$, kadar glukosa darah dua jam adalah 80 sampai $144 \mathrm{mg} / \mathrm{dl}$, dan kadar HB A1c kurang dari tujuh persen. Pengukuran hemoglobin ( $\mathrm{Hb})$ terglikosilasi HBA1c (A1c) adalah cara yang paling akurat untuk menentukan tingkat ketinggian gula darah selama dua sampai tiga bulan terakhir.

Hemoglobin adalah bagian dari sel darah merah yang mengangkut oksigen. Salah satu jenis dari $\mathrm{Hb}$ adalah $\mathrm{HbA}$ dan $\mathrm{HbA} 1 \mathrm{c}$ merupakan subtipe spesifik dari $\mathrm{HbA}$, (Ruslianti, 2008). Semakin tinggi kadar glukosa darah, akan semakin cepat HbA1c terbentuk, yang mengakibatkan tingginya kadar HbA1c. HbA1c ini juga merupakan pemeriksaan tunggal terbaik untuk menilai risiko terhadap kerusakan jaringan yang disebabkan oleh tingginya kadar gula darah. Contohnya, pada syaraf dan pembuluh darah kecil di mata dan ginjal. Selain itu, juga bisa menilai risiko terhadap komplikasi penyakit diabetes.

\section{Gejala Penderita Diabetes}

Gejala klinis yang khas pada DM yaitu "Tria poli” polidipsi (banyak minum), poli phagia (banyak makan) dan poliuri (banyak kencing), di samping disertai dengan keluhan sering kesemutan terutama jari-jari tangan, badan terasa lemas, gatal-gatal dan bila ada luka sukar sembuh. Kadang-kadang BB menurun secara drastis. Untuk mengetahui apakah seorang menderita DM, yaitu dengan memeriksakan kadar gula darah (Gklinis, 2004). Kadar gula darah normal adalah:

\section{Pada saat puasa (nuchter : $80-<110 \mathrm{mg} / \mathrm{dl}$ Setelah makan : $110-<160 \mathrm{gr} / \mathrm{dl}$}

Menurut Unggu Pribadi (2006) jika kadar gula darah terus menerus tinggi ini berarti tidak terkontrol, lama kelamaan akan timbul penyulit (komplikasi) yang pada dasarnya terjadi pada semua pembuluh darah, misalnya: pembuluh darah otak (stroke), pembuluh darah mata (dapat terjadi kebutaan), pembuluh darah ginjal (GGH hemodialisa) dll. Jika sudah terjadi penyulit ini, maka usaha untuk menyembuhkan keadaan tersebut ke arah 
normal sangat sulit. Oleh karena itu, usaha pencegahan dini untuk penyulit tersebut diperlukan dan diharapkan sangat bermanfaat untuk menghindari terjadinya berbagai hal yang tidak menguntungkan.

\section{INSULIN}

Insulin adalah hormone alami yang dikeluarkan oleh pankreas. Insulin dibutuhkan oleh sel tubuh untuk mengubah dan menggunakan glukosa darah (gula darah), dari glukosa, sel membuat energi yang dibutuhkan untuk menjalankan fungsinya. Pasien diabetes mellitus tidak memiliki kemampuan untuk mengambil dan menggunakan gula darah, sehingga kadar gula darah meningkat. Pada diabetes tipe I, pancreas tidak dapat memproduksi insulin. Sehingga pemberian insulin diperlukan. Pada diabetes tipe 2, pasien memproduksi insulin, tetapi sel tubuh tidak merespon insulin dengan normal. Namun demikian, insulin juga digunakan pada diabetes tipe 2 untuk mengatasi resistensi sel terhadap insulin. Dengan peningkatan pengambilan glukosa oleh sel dan menurunnya kadar gula darah, akan mencegah dan mengurangi komplikasi lebih lanjut dari diabetes, seperti kerusakan pembuluh darah, mata, ginjal, dan syaraf. Insulin diberikan dengan cara disuntikan di bawah kulit (subkutan). Jaringan subkutan perut adalah yang terbaik karena penyerapan insulin lebih konsisten dibanding tempat lainnya. Terdapat banyak bentuk insulin. Insulin diklasifikasikan berdasarkan dari berapa cepat insulin mulai bekerja dan berapa lama insulin bekerja (www.webmd.com).

Tipe insulin terdiri atas:

1. Aksi cepat (rapid acting)

2. Aksi pendek (short acting)

3. Aksi menengah (intermediate acting)

4. Aksi lama (long-acting)

5. Campuran (Pre-mixed)

Pemilihan tipe insulin tergantung pada beberapa faktor, yaitu:

1. Respon tubuh individu terhadap insulin (berapa lama menyerap insulin ke dalam tubuh dan tetap aktif di dalam tubuh sangat bervariasi dari setiap individu).

2. Pilihan gaya hidup, seperti: jenis makanan, berapa banyak konsumsi alkohol, berapa sering berolahraga, yang semuanya mempengaruhi tubuh untuk merespon insulin.

3. Berapa banyak suntikan per hari yang ingin dilakukan.

4. Berapa sering melakukan pengecekan kadar gula darah.

5. Usia

6. Target pengaturan gula darah.

Pada tabel didiskripsikan berbagai insulin dan cara kerjanya dalam tubuh. Sebagai keterangan, insulin injeksi dengan data: onset (lamanya waktu yang dibutuhkan untuk insulin mencapai darah dan mulai menurunkan kadar gula darah, peak (periode waktu dimana insulin paling efektif menurunkan gula darah), dan duration (berapa lama insulin 
terus menurunkan kadar gula darah). Ketiga faktor ini mungkin bervariasi, tergantung respon tubuh seseorang. Kolom terakhir menjelaskan bagaimana hubungan jenis insulin dengan waktu makan.

\section{Tabel 1. Macam-Macam Insulin dan Cara Kerja dalam Tubuh} (sumber : www.medicinenet.com)

\begin{tabular}{|c|c|c|}
\hline $\begin{array}{c}\text { Jenis } \\
\text { insulin }\end{array}$ & Waktu & Aturan Pengaturan Gula Darah \\
\hline \multicolumn{2}{|c|}{ Rapid-Acting } & \multirow{4}{*}{$\begin{array}{l}\text { Digunakan bersamaan makan. Jenis ini digunakan } \\
\text { bersamaan dengan jenis insulin longer-acting. }\end{array}$} \\
\hline $\begin{array}{l}\text { Onset } \\
\text { menit }\end{array}$ & $15-30$ & \\
\hline $\begin{array}{l}\text { Peak } \\
\text { menit }\end{array}$ & $30-90$ & \\
\hline Duration & $1-5$ jam & \\
\hline \multicolumn{2}{|c|}{ Short Acting } & \multirow{4}{*}{$\begin{array}{l}\text { Digunakan untuk mencukupi insulin setelah } \\
\text { makan 30-60 menit. }\end{array}$} \\
\hline Onset & $1 / 2-1 \mathrm{jam}$ & \\
\hline Peak & $2-5$ jam & \\
\hline Duration & $2-8$ jam & \\
\hline \multicolumn{2}{|c|}{ Intermediate-Acting } & \multirow{4}{*}{$\begin{array}{l}\text { Digunakan untuk mencukupi insulin selama } \\
\text { setengah hari atau sepanjang malam. Jenis ini } \\
\text { biasa dikombinasi dengan jenis rapid-acting atau } \\
\text { short-acting. }\end{array}$} \\
\hline Onset & $1-21 / 2 \mathrm{jam}$ & \\
\hline Peak & 3-12 jam & \\
\hline Duration & $18-24$ jam & \\
\hline \multicolumn{2}{|c|}{ Long-Acting } & \multirow{4}{*}{$\begin{array}{l}\text { Digunakan untuk mencukupi insulin seharian. } \\
\text { Jenis ini biasa dikombinasi dengan jenis rapid- } \\
\text { acting atau short-acting. }\end{array}$} \\
\hline Onset & $1 / 2-3$ jam & \\
\hline Peak & 6-20 jam & \\
\hline Duration & 20-36 jam & \\
\hline \multicolumn{2}{|c|}{ Pre-Mixed* } & \multirow{4}{*}{$\begin{array}{l}\text { Produk ini biasanya digunakan dua kali sehari } \\
\text { sebelum makan. Premixed insulin adalah } \\
\text { kombinasi dengan proporsi yang spesifik insulin } \\
\text { intermediate-acting dan insulin short-acting } \\
\text { insulin di satu botol atau insulin pen. }\end{array}$} \\
\hline $\begin{array}{l}\text { Onset } \\
\text { menit }\end{array}$ & $10-30$ & \\
\hline Peak & $1 / 2-12 \mathrm{jam}$ & \\
\hline $\begin{array}{l}\text { Duration } \\
\text { lebih }\end{array}$ & 14-24 jam & \\
\hline
\end{tabular}


Jangka waktu antara memakai insulin dan makan mungkin bervariasi tergantung pada jenis insulin yang digunakan. Pada tabel di atas, data onset adalah informasi yang berguna kapan insulin bekerja di dalam tubuh bersamaan dengan waktu makan. Penentuan waktu ini membantu mencegah kadar gula darah terlalu rendah (www.medicienet.com).

\section{Manfaat Insulin bagi Penderita Diabetes}

Masih terdapatnya beberapa kendala penggunaan insulin sering menyebabkan keterlambatan kendali glukosa darah yang baik bagi pasien Diabetes mellitus. Menurut Gklinis (2004) pasien DM Tipe 2 (DMT2) yang memiliki kontrol glukosa darah yang tidak baik dengan penggunaan obat antidiabetik oral perlu dipertimbangkan untuk penambahan insulin sebagai terapi kombinasi dengan obat oral atau insulin tunggal. Insulin yang diberikan lebih dini dan lebih agresif menunjukkan hasil klinis yang lebih baik terutama berkaitan dengan masalah glukotoksitas. Hal tersebut diperlihatkan oleh perbaikan fungsi sel beta pancreas. Insulin juga memiliki efek lain yang menguntungkan dalam kaitannya dengan komplikasi DM. Terapi insulin dapat mencegah kerusakan endotel, menekan proses inflamasi, mengurangi kejadian apoptosis, dan memperbaiki profil lipid. Dengan demikian, secara ringkas dapat dikatakan bahwa luaran klinis pasien yang diberikan terapi insulin akan lebih baik. Insulin, terutama insulin analog, merupakan jenis yang baik, karena memiliki profil sekresi yang sangat mendekati pola sekresi insulin normal atau fisiologis.

Pada awalnya, terapi insulin hanya ditujukan bagi pasien diabetes mellitus tipe 1 (DMT1), namun demikian pada kenyataannya, insulin lebih banyak digunakan oleh pasien DMT2 karena prevalensi DMT2 jauh lebih banyak dibandingkan DMT1. Terapi insulin pada DMT2 dapat dimulai antara lain untuk pasien dengan kegagalan terapi oral, kendali kadar glukosa darah yang buruk (A1c $>7,5 \%$ atau kadar glukosa darah puasa $>250$ $\mathrm{mg} / \mathrm{dl}$ ), riwayat pankreatektomi atau disfungsi pancreas, riwayat fluktuasi kadar glukosa darah yang lebar, riwayat ketoasidodis, riwayat penggunaan insulin lebih dari 5 tahun dan penyandang DM lebih dari 10 tahun.

Pada pasien DMT1, pemberian insulin yang dianjurkan adalah injeksi harian multipel dengan tujuan mencapai kendali kadar glukosa darah yang baik. Selain itu, pemberian dapat juga dilakukan dengan menggunakan pompa insulin (continous subcutaneous insulin infusion, CSII). Ada beberapa cara untuk memulai dan menyesuaikan dosis terapi insulin untuk pasien DMT2.

Salah satu cara yang paling mutakhir dan dapat dipakai sebagai acuan adalah hasil Konsensus PERKENI 2006 dan Konsensus ADA-EASD tahun 2006. Sebagai pegangan, jika kadar glukosa darah tidak terkontrol dengan baik, $\mathrm{Hb}(\mathrm{A} 1 \mathrm{C}>7,5 \%)$ dalam jangka waktu 3 bulan dengan 2 obat oral, maka sudah ada indikasi untuk memulai terapi kombinasi obat antidiabetik oral dan insulin. Pada keadaan tertentu dimana kendali glikemik amat buruk dan disertai kondisi katabolisme, seperti kadar glukosa darah puasa $>250 \mathrm{mg} / \mathrm{dl}$, 
kadar glukosa darah acak menetap $>300 \mathrm{mg} / \mathrm{dl}, \mathrm{Hb}$ A1C $>10 \%$, atau ditemukan ketonuria, maka terapi insulin dapat mulai diberikan bersamaan dengan intervensi pola hidup. Selain itu, terapi insulin juga dapat langsung diberikan pada pasien DM yang memiliki gejala nyata (poliuri, polifagia dan penurunan berat badan). Kondisi-kondisi tersebut sering ditemukan pada pasien DMT1 atau DMT2dengan defisiensi insulin yang berat. Apabila gejala hilang, obat antidiabetik oral dapat ditambahkan dan penggunaan insulin dapat dihentikan. Seperti telah diketahui, pada pasien DM terjadi gangguan sekresi insulin basal dan prandial untuk mempertahankan kadar glukosa darah dalam batas normal baik pada keadaan puasa maupun setelah makan. Dengan demikan bahwa hakikat pengobatan DM adalah menurunkan kadar glukosa darah baik puasa maupun setelah makan.

Dalam rangka mencapai sasaran pengobatan yang baik, maka diperlukan insulin dengan karakteristik menyerupai orang sehat, yaitu kadar insulin yang sesuai dengan kebutuhan basal dan prandial. Pemberian insulin basal, selain insulin prandial, merupakan salah satu strategi pengobatan untuk memperbaiki kadar glukosa darah puasa atau sebelum makan. Oleh karena glukosa darah setelah makan merupakan keadaan yang dipengaruhi oleh kadar glukosa darah puasa, maka diharapkan dengan menurunkan kadar glukosa darah basal, kadar glukosa darah setelah makan juga ikut turun. Cara pemberian insulin basal dapat dilakukan dengan pemberian insulin kerja cepat drip intravena (hanya dilakukan pada pasien rawat inap), atau dengan pemberian insulin kerja panjang secara subkutan.

Idealnya, sesuai dengan keadaan fisiologis tubuh, terapi insulin diberikan sekali untuk kebutuhan basal dan tiga kali dengan insulin prandial untuk kebutuhan setelah makan. Namun demikian, terapi insulin yang diberikan dapat bervariasi sesuai dengan kenyamanan penderita selama terapi insulin mendekati kebutuhan fisiologis. Walaupun banyak cara yang dapat dianjurkan, namun prinsip dasarnya adalah sama, yaitu insulin prandial dikombinasikan dengan insulin basal dalam usaha untuk menirukan sekresi insulin fisiologis.

\section{Cara Lain Mencegah dan Mengobati Diabetes}

DM dapat dicegah dengan menerapkan hidup sehat sedini mungkin, yaitu dengan mempertahankan pola makan sehari-hari yang sehat dan seimbang dengan meningkatkan konsumsi sayuran, buah dan serat, membatasi makanan yang tinggi karbohidrat, protein dan lemak, mempertahankan BB yang normal sesuai dengan umur dan tinggi badan (TB) serta Olahraga (OR) teratur sesuai umur dan kemampuan. Tujuan pengobatan penderita DM ialah: Untuk mengurangi gejala, menurunkan BB bagi yang kegemukan dan mencegah terjadinya komplikasi (GKlinis, 2004). Di bawah ini adalah cara lain untuk mengobati Diabetes Mellitus, diantaranya adalah:

1. Diet: penderita DM sangat dianjurkan untuk menjalankan diet sesuai dengan yang dianjurkan, yang mendapat pengobatan anti diuretic atau insulin, harus mentaati diet terus menerus baik dalam jumlah kalori, komposisi dan waktu makan harus diatur. Ketaatan ini sangat diperlukan juga pada saat: undangan/pesta, melakukan perjalanan, olahraga (OR) dan aktivitas lain. 
2. Obat-obatan, tablet/suntikan anti diabetes diberikan, namun therapi diet tidak boleh dilupakan dan pengobatan penyulit lain yang menyertai/suntikan insulin.

3. Olahraga: dengan olahraga teratur sensitivitas sel terhadap insulin menjadi lebih baik, sehingga insulin yang ada walaupun relative kurang, dapat dipakai dengan lebih efektif. Lakukan olahraga 1-2 jam sesudah makan terutama pagi hari selama $1 / 2-1$ jam perhari minimal 3 kali/4minggu.

\section{KESIMPULAN}

Penyakit kencing manis ini telah lama diketahui manusia. Beribu-ribu penduduk dunia baik di Negara maju ataupun Negara sedang berkembang mengidap penyakit ini. Penyakit kencing manis tidak seharusnya menjadi satu penghalang untuk kehidupan yang normal. Dengan bertambahnya pengetahuan mengenai penyakit kencing manis dan adanya obat-obatan untuk penyakit ini serta peralatan kesehatan modern seperti alat kontrol gula darah serta "pompa insulin", bukanlah penyebab mengapa anda tidak boleh hidup seperti manusia normal dan panjang umur.

Penyakit kencing manis adalah satu keadaan di mana terdapat kadar gula yang berlebihan dalam peredaran darah. Ini terjadi karena tubuh kita kekurangan sesuatu hormone yang disebut "insulin" yang diperlukan untuk mengubah gula darah (glukosa) menjadi energi. Insulin adalah sejenis hormone yang dihasilkan oleh organ bernama pancreas yang terletak di bawah perut. Tubuh kita membutuhkan energi dari makanan untuk menjalankan tugas keseharian kita. Dalam perut kita, makanan berkarbohidrat diubah menjadi gula darah atau glukosa dan masuk ke dalam saluran darah di mana ia akan digunakan oleh tubuh untuk menghasilkan energi. Glukosa adalah penghasil utama energi tubuh.

Dalam keadaan biasa, insulin membantu glukosa dalam darah untuk memasuki selsel tubuh untuk diubah menjadi energi. Bagi penderita penyakit kencing manis, organ pancreas tidak dapat menghasilkan hormone insulin dengan secukupnya atau insulin yang dikeluarkan tidak dapat bertindak seperti biasa. Akibatnya, glukosa atau gula darah tidak dapat memasuki sel-sel tubuh. Kadar glukosa dalam peredaran darah menjadi tinggi. Glukosa yang berlebihan ini akan disingkirkan oleh tubuh melalui air kencing. Inilah sebabnya, penyakit ini dikenali sebagai "Penyakit Kencing Manis". Tanpa insulin, sel-sel tubuh tidak menerima cukup glukosa, walaupun kadarnya amat tinggi dalam peredaran darah. Ini menyebabkan tubuh akan kekurangan energi.

\section{DAFTAR PUSTAKA}

Gklinis dalam "Republika Online Edisi-Selasa, 27 Juli 2004- Penulis : mag, Menu sehat untuk Pengidap Diabetes Mellitus Sabtu, 31 Juli, 2004.

Muhammad Ridwan Thahir (2008), Pompa Insulin, Alat Mutakhir untuk Penderita Diabetes Mellitus Jakarta : Cetakan Kedua, Demedia. 
Risky Perdana (PERKENI). Petunjuk Praktis. Terapi Insulin pada Pasien Diabetes Melitus. Pusat Penerbitan Ilmu Penyakit Dalam FKUI, Jakarta, 2008. Hal. 9-12.

Ruslianti, (2008). Pengobatan Diabetes melalui Pola Makan, Jakarta : Kawan Pustaka.

Soegianto Wibisono (2009), Diabetes dan Pengobatannya, dalam www. Insulin_go.com, diakses pada tanggal 20 Januari 2010.

Unggul Pribadi, (2006). Kupas Tuntas Diabetes. Majalah Harmoni. Jakarta.

www.webmd.com dan www.medicinene.com diakses pada 4 Februari 2010. 